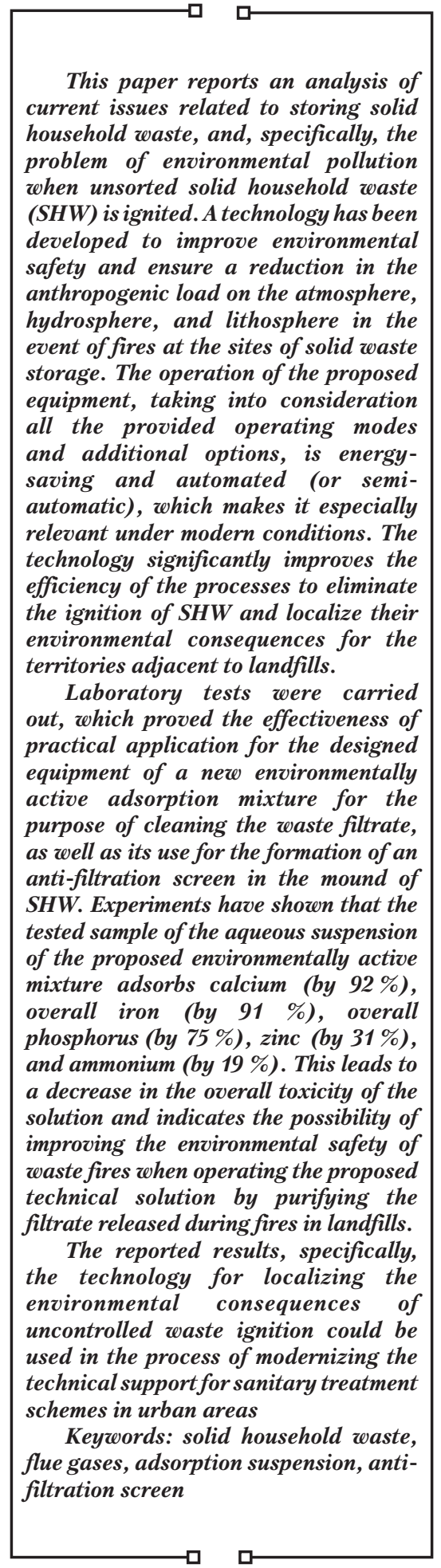

\title{
DEVISING THE TECHNOLOGY FOR LOCALIZING ENVIRONMENTAL POLLUTION DURING FIRES AT SPONTANEOUS LANDFILLS AND TESTING IT IN THE LABORATORY
}

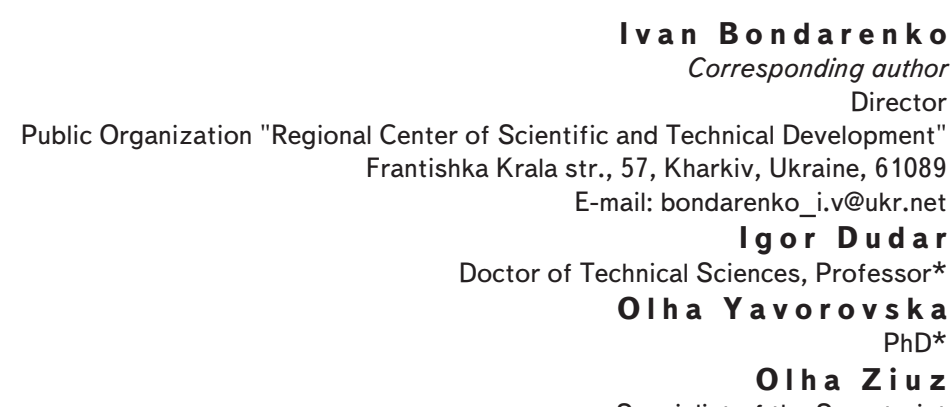

Specialist of the Secretariat The Committee of the Verkhovna Rada of Ukraine on Environmental Policy and Utilization of Natural Resources Hrushevskoho str., 5, Kyiv, Ukraine, 01008

Sergi Boichenko Doctor of Technical Sciences, Professor Department of Ecology***

Ihor Kuberskyi Postgraduate Student, Director LLC "SOBIHRUP"

Drahomanova str., 40, Kyiv, Ukraine, 02068

Iryna Shkilniuk $\mathrm{PhD}$

Ukrainian Scientific-Research and Training Center for Chemmotology and Certification of Lubricants and Industrial Fluids National Aviation University

Liubomyra Huzara ave., 1, Kyiv, Ukraine, 03058

Bohdana Komarysta $\mathrm{PhD}$, Associate Professor**

Iryna Dzhygyrey $\mathrm{PhD}$, Associate Professor**

VIadyslav Bendiuh $\mathrm{PhD}$, Associate Professor** *Department of Construction, Municipal Economy and Architecture Vinnytsia National Technical University Khmelnytske shosse str., 95, Vinnytsia, Ukraine, 21021 **Department of Mathematical Methods of System Analysis** Educational and Scientific Complex «Institute of Applied Systems Analysis»*** ***National Technical University of Ukraine "Igor Sikorsky Kyiv Polytechnic Institute" Peremohy ave., 37, Kyiv, Ukraine, 03056

\section{Introduction}

An important condition for the sustainable development of the world economy is the implementation of an ecological approach to economic activities in various sectors and industries [1]. It is becoming clear that it is necessary to reorganize the economy in such a way that human industrial activity is fully integrated into an effective environmental infrastructure. And one of the cornerstones of creating a stable economic system within the state is the effective and environmentally sound management of waste. The issue of waste has recently come to the fore among other environmental problems [2]. 
Insufficient complexity of the use of raw materials and imperfection of industrial technologies, a sharp increase in the population with a change in the quality of life causes the formation of more waste than the processing systems operating in the state can process. The issue of proper management of anthropogenic waste is of global importance for the preservation of the ecological system [3, 4]. Therefore, it is necessary to constantly improve the methods of effective treatment of generated waste, replenishment, or replacement of consumed resources, as well as methods of safe disposal of already accumulated solid household waste (SHW). One of the tasks that require solving and conducting appropriate research is the environmentally rational disposal of already accumulated waste and minimizing the anthropogenic load on the natural environment of SHW storage facilities. More than 10 thousand hectares of the country's territories today are already buried under millions of tons of waste, which, at sites of unauthorized storage, pose a huge environmental danger. The absence of a separate collection system in spontaneous landfills, where the hazardous waste of various morphological diversity and chemical composition accumulates uncontrollably, in the process of decay leads to the concentration of hazardous toxicants and pollutants in the body of the landfill [5, 6].

Penetration into the soil and groundwater of landfill filtrate, as well as atmospheric emissions during fires for many years systematically pollute the environment and pose a threat to human health. The introduction of the latest technologies, the improvement of environmental culture, compliance with the requirements of accepted environmental standards, the search for effective tools for the implementation of environmental and economic management of enterprises, territories, and regions is a necessary component of the future sustainable development of the country. In turn, the practical implementation of the principles of environmentally sustainable development of the socio-economic systems necessitates the improvement of methods, techniques, and tools for organizing production based on the ecologization of the logistics management system. Thus, the study of the waste management process in the world today is especially relevant. Given the urgent need to improve the environmental safety of the storage of unsorted waste, it is considered relevant to modernize the technical support for sanitary treatment schemes in urban areas.

\section{Literature review and problem statement}

The issues of the negative impact of stored waste on the natural environment and on human health have been actively studied for more than half a century. The problem is gaining particular relevance due to the introduction of new technologies into human life, intensive urbanization of the population, increased use of polymer packaging materials, etc. Analysis of study [7] makes it possible to conclude that active waste disposal and recycling is used on average only for $3-5 \%$ of the total volume of SHW. This, as stated in work [8], leads to the formation of a huge number of landfills and spontaneous unauthorized landfills. One of the most dangerous processes affecting the environment is the burning of waste in landfills.

From work [9], it follows that the most used approach to assessing the ecological state of the environment today is to collect data on the content of chemicals and compare their content with the norms set out by MAC. However, it is important to note that pollution standards are only available for a limited number of chemical pollutants.

The analysis of work [10] indicates a lack of research into the problem of the complex environmental impact of mixtures of chemicals, including compounds, which are formed during the uncontrolled thermal decomposition of unsorted waste.

In work [11], the authors consider the main aspects of environmental pollution during a fire in SHW landfills. Concentrations of polycyclic aromatic hydrocarbons, polychlorinated biphenyls, organochlorine pesticides, including hexachlorocyclohexanes and DDT were assessed as the main pollutants. The results of the study showed that, despite minor exceedances, the levels of soil and vegetation pollution in the vicinity of the landfill are comparable to the average levels of pollution of other industrial and economic territories. The impact of the fire at the landfill, in this case, was not obvious in part due to the effects on the study areas of other activities, earlier fires in landfills, etc.

In [12], the authors assess the fire hazard of the landfill, analyze the causes and risks of fire events. To reduce the likelihood of fires at the landfill, the authors of the study propose the separation of organic components from the total mass of waste entering the landfill, which serve as a source of biogas formation. However, this method excludes only one of the possible causes of the ignition of stored waste, and does not solve the problem of fire hazard of existing landfills. Extinguishing fires in landfills is often hampered by the difficulty of quick access to the source of ignition due to the peculiarities of waste storage, as well as the unpredictable flammability of the extinguished material.

The consequences of burning waste in open landfills were also analyzed by the authors of work [13] who assessed the composition of brown-hue precipitation that fell after a strong fire at the landfill. Theoretically, it was confirmed that a mixture of materials with a diverse chemical structure as a result of combustion leads to several chemicals with a great potential for danger to human health [14]. An additional environmental hazard is the possible use of special fire-extinguishing mixtures, the chemical compatibility of which is difficult to predict with an uncontrolled composition of a garbage dump. Among the detected hazardous substances in the studied samples were dioxins and furans, pyridines, pyrroles, imines and oximes, sulfoxides, sulfones, thiols, sulfides, cyanates, cyanides, diazo components, epoxides and peroxides, formeates, benzoates. It is worth noting that some of the tests were conducted a few months after the fire at the landfill. This indicates the persistent toxicity of pollutants not only in the atmosphere but also in soil "treated" with such rain and exposed to the effects of climatic fumes.

Paper [15] reports the results of the analysis of atmospheric emissions during the operation of open waste dumps, including when they catch fire. It was found that dangerous vapor-gas emissions are more than 3.5 times more intense during combustion than during fire-safe aerobic storage [16]. As a reduction in the impact of landfills on the atmosphere, the authors consider an innovative method of semi-aerobic burial. However, it is worth noting that the general trend of changes in the methods of deposition does not make it possible to reduce and localize atmospheric emissions from fires in existing landfills.

In work [17], it is noted that during fires in landfills as a whole, the average daily concentrations of such atmospheric 
indicators as $\mathrm{PM}_{2,5}, \mathrm{NO}_{2}$, and $\mathrm{O}_{3}$ in the nearest settlements almost did not change. However, the concentrations of potentially toxic substances, including benzene and dioxins/furans, were significantly increased. In addition, levels of dioxins/furans in the atmosphere exceeded toxicological standards [18], negatively affecting the general condition as well as the reproductive aspects of public health [19]. According to study [20], when dispersed particles smaller than $10 \mu \mathrm{m}\left(\mathrm{PM}_{10}\right)$ are emitted by burning waste, the risk of cancer in the population living in the landfill area could increase by 70.15 times. The authors of [17] note that atmospheric monitoring does not examine the indicators of many pollutants; in the above works, the concentration values may be underestimated in areas that do not affect the polluting plume.

In [21], the authors analyzed the dynamics of dioxin accumulation in soil and food samples after a fire in a landfill. Thus, the results of a study of pollution with polychlorinated biphenyls indicate an inverse correlation between dioxin pollution and the distance from the source of pollution, which indicates the specificity of their distribution in the atmosphere. At the same time, questions related to the formation of dangerous toxicants, as well as the development of practical methods to combat their spread, remain open in the cited work.

As shown by study [22], the isolation of carcinogenic polychlorinated rhodibenzodioxins and polychlorinated dibenzofurans during low-temperature waste combustion in the composition of the emitted dispersed ash dust was observed in almost the entire range of studied waste combustion temperatures. At the same time, the maximum emission (equivalent to more than 42 times the total concentration of dioxin/furan in the initial fly ash) was observed at a fly ash temperature of $350{ }^{\circ} \mathrm{C}$. Given the extreme danger of carcinogens, such results force to take categorical measures to increase the fire safety of landfills and intensive fire elimination, the development of which the authors of the cited work left for further research.

Separately, worth noting is the negative impact on the environment and public health of landfill filtrate. This topic has been actively studied for several decades but it still remains relevant for most countries of the world [23]. Contamination of soils and groundwater with toxic chemical compounds, radioactive elements, and heavy metals, which are present in landfill filtrate, leads to dangerous consequences for humans. Among them are critical lesions of internal organs (circulatory, genitourinary, digestive systems) in people living near the test site [24]. Many methods have been proposed to reduce the negative effects of filtrate [25]. Among the most innovative techniques worth noting is the technology of treating filtrate using an integrated reactor (SBR), the reverse osmosis (RO) process described in [26], and the application of promising membrane technologies proposed in [25]. However, in the analyzed works [25, 26], the authors to a greater extent consider the options for cleaning already contaminated natural components while paying minimal attention to the neutralization and reduction of the amount of landfill filtrate released into the environment. In addition, the complex issue of increasing the environmental hazard of filtrate in case of fires in waste storage areas remains ignored. An increase in the temperature in the body of the landfill during a fire leads to an intensification of the decomposition of organic components, the disintegration of components of waste of high hazard classes. This causes the release into the environment of more hazardous to the life and health of the population compounds [27] in the composition of atmospheric emissions and filtrate. Such a complex problem is of particular relevance in countries with the absence of separate garbage collection and the presence of waste of all hazard classes in unauthorized open landfills.

An option for solving such problems under the conditions of open landfills with an unpredictable morphological composition may be the development of an aggregate system that ensures the localization of the environmental consequences of uncontrolled waste ignition and the simultaneous reduction of the toxicological hazard of filtrate.

\section{The aim and objectives of the study}

The purpose of this study is to devise and test practically the technology of effective, comprehensive reduction of environmental pollution in case of fires at SHW landfills and under the conditions of waste fires at unauthorized landfills. This will make it possible to use the results of the study in the process of modernizing the technical support for sanitary treatment schemes in urban areas.

To accomplish the aim, the following tasks have been set:

- to devise technology for localizing environmental risks in case of fires at sites of waste accumulation;

- to experimentally substantiate the effectiveness and practical applicability of the designed technological system.

\section{The study materials and methods}

The theoretical part of the study is carried out using methods and techniques for developing technical solutions according to the theory of solving inventive problems [28].

Underlying the selection of methods of practical tests of the devised technology is the goal to establish the adsorption properties of an apparatus mixture when it treats a sample of the SHW filtrate - one of the main uncontrolled pollutants in the process of ignition of waste. Indicators of the composition and properties of the filtrate from an SHW landfill, taken under control for the purpose of research, include basic characteristics such as $\mathrm{pH}$, total phosphorus, ammonium ions, calcium ions, iron ions, zinc ions, chemical oxygen consumption (COC). Samples of the SHW filtrate before and after treatment were examined in parallel by measuring the level of indicators according to the following procedures:

1. MVI No. 081/12-0317-06 Surface, groundwater, and reverse water. Procedure to perform measurements of the $\mathrm{pH}$ index $(\mathrm{pH})$ by the electrometric method [29].

2. MVI No. 081/12-0106-03 Surface, groundwater, and reverse water. Procedure to measure the mass concentration of ammonium ions by photocolorimetry involving the Nessler reagent [30].

3. DSTU EN ISO 11885:2019 Water quality. Determining selected elements by inductively coupled plasma optical emission spectrometry (ICP-OES) (EN ISO 11885:2009, IDT; ISO 11885:2007, IDT).

4. MVI No. 081/12-0647-09 Reverse, surface, underground water. Procedure to perform the measurements of chemical oxygen consumption (COC) by spectrophotometric method [31]. 
The place of sampling of the filtrate sample is the Dergachev SHW landfill (Kharkiv oblast, Ukraine). Date of the sample collection: 05.10.2021.

According to the methodology of laboratory tests and the basic formula of the developed active composite adsorbent, a prototype of an aqueous suspension of an environmentally active mixture was prepared. We added, to $75.00 \mathrm{~g}$ of the mixture in the form of a dry powder, $75.00 \mathrm{~cm}^{3}$ of distilled water. Further, the suspension was mixed by a magnetic stirrer for $120 \mathrm{~min}$. at a speed of $1,000 \mathrm{rpm} .50 \mathrm{~g}$ of the resulting suspension was mixed with $750 \mathrm{~g}$ of the filtrate from the SHW landfill. The experimental mixture was agitated by a magnetic stirrer at a speed of $1,000 \mathrm{rpm} 5$ times over 10 minutes. After that, the treated filtrate was left for 16 hours. In the calculations of the composition indicators and properties of the filtrate after treatment, the dilution factor was taken into consideration due to the water available in the adsorbent, namely, the results were multiplied by a coefficient equal to $1+75 /(75+750) \sim 1.09$. We evaluated the effectiveness of the adsorbent according to the following indicators:

1) Percentage of removal of pollutants $B, \%$, calculated from (1)

$$
B, \%=100-\frac{w_{1}}{w_{2}} \cdot 100
$$

where $w_{1}$ and $w_{2}$ is the mass concentration after treatment and before treatment, respectively.

2) The adsorbent capacity was calculated from (2):

$$
C=\left(w_{2}-w_{1}\right) \times 0.750 / 0.150=\left(w_{2}-w_{1}\right) \times 5,(\mathrm{mg} / \mathrm{kg}) .
$$

3) The capacity of the adsorbent, \% relative to the content in the studied filtrate, was determined from (3):

$$
C, \%=\frac{c}{w_{2}} \cdot 100 \%
$$

The system of measurements of controlled indicators used for testing under the laboratory conditions meets the requirements set out by DSTU (DSTU ISO 10012: 2005. Measurement control systems. Requirements for measurement processes and measuring equipment).

\section{Results of devising and investigating the effectiveness of technology for improving environmental safety in the case of waste ignition}

5. 1. The technology of localization of environmental risks in the cases of fires at sites of waste accumulation

Based on the results of studying issues related to environmental pollution during fires at SHW landfills, we have devised technology for localizing the environmental risks of waste ignition, through the use of a specialized hardware system. This technological advancement is aimed at reducing the environmental consequences of the uncontrolled distribution of thermal decomposition products of waste substandard materials [32]. The technical system involves technology for air purification from suspended particles of photochemical smog and volcanic ash [33]. The main version of the basic device of the system in question includes a rigid frame with bearing plates and a circular cylindrical support wall with a cutout in its structure (Fig. 1).

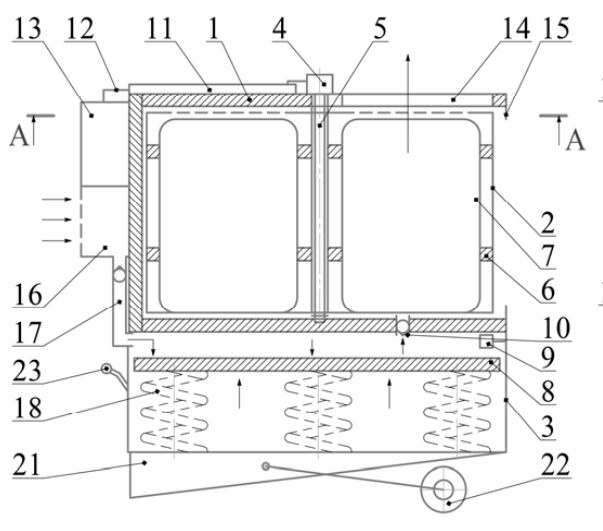

$a$

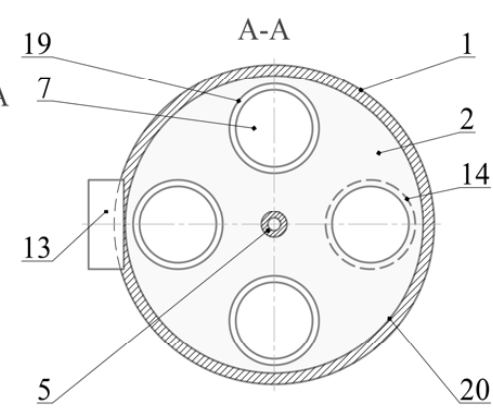

Fig. 1. Diagram of the main version of the basic device in the system for 作

$a$ - longitudinal projection; $b$ - transverse projection: 1 - rigid frame; - support; 7 - starting unit; 8 - plate piston; 9 - pressure - starting tube; 11 - solar panel; 12 - cable; 13 - rechargeable - hatch; 15 - limiter; 16 - compressor; 17 - pneumatic pipe; 22 - transport wheel; 23 - operator's knob

The wall is connected to power pneumatic tank 3 containing inside a plate piston 8 , connected, in turn, to spring elements 18 (Fig. 1). The apparatus also includes a rotating exhaust drum 2 with vertical hollow compartments having a movable connection to power shaft 5 . The upper bearing plate of frame 1 is made with a hole that closes with lid 14, coinciding with the compartments of exhaust drum 2 when the latter rotates. The lower bearing plate is equipped with a valveequipped starting tube 10 for the release of compressed air from pneumatic tank 3 to the compartments of exhaust drum 2 with the subsequent displacement of the launch units [32] containing carriers of the working sorption mixture. The electric motor connected to power shaft 5 is connected via cable 12 to the photovoltaic converter 11 ("solar battery") powering it. Battery 11 is connected to a unit of the rechargeable battery 13 and compressor 16 , which is connected by pipe 10 to the pneumatic tank 3 (Fig. 1). The lower part of the apparatus has a sharper 21 for fixing the device in the ground, and wheel 22 for its transportation.

The structure may additionally be equipped with tank 32 containing a suspension of the active substance. The tank is equipped with a spring-piston mechanism 2627 for mixing and displacing the suspension under high pressure through sprayers 36 located on the rotating coupling 25 (Fig. 2) [32, 33]. 


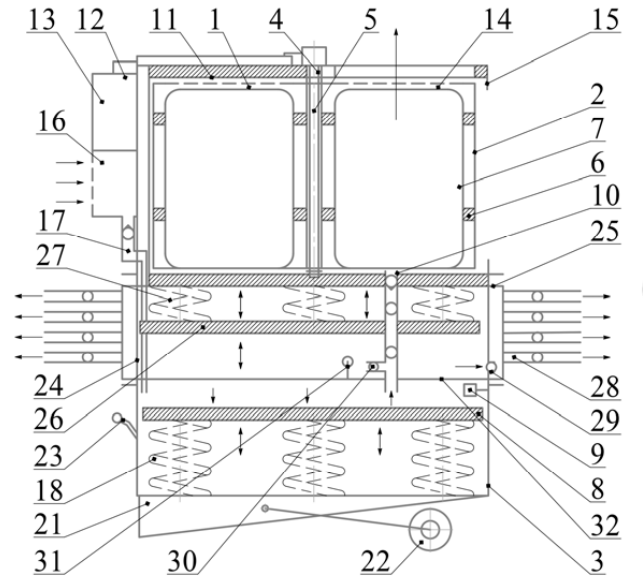

$a$

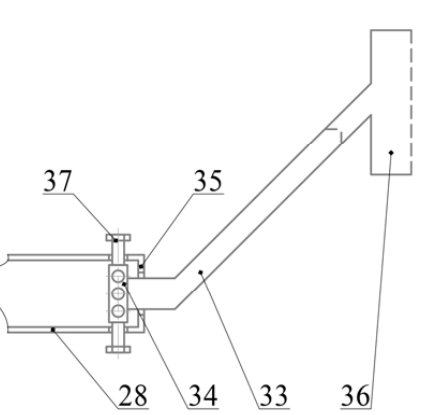

$\begin{array}{llll}28 & 34 & 33 & 36\end{array}$

flue gases to form environmentally friendly substances, entering the following reactions with them (4) to (10):

$$
\begin{aligned}
& \mathrm{SO}_{2}+\mathrm{Mg}(\mathrm{OH})_{2}=\mathrm{MgSO}_{3}+\mathrm{H}_{2} \mathrm{O} \\
& \mathrm{Ca}(\mathrm{OH})_{2}+\mathrm{SO}_{2} \rightarrow \mathrm{CaSO}_{3}+\mathrm{H}_{2} \mathrm{O} \\
& \mathrm{Ca}(\mathrm{OH})_{2}+\mathrm{SO}_{2}+\mathrm{O}_{2} \rightarrow \mathrm{CaSO}_{4}+\mathrm{H}_{2} \mathrm{O} ;(6) \\
& \mathrm{Ca}(\mathrm{OH})_{2}+\mathrm{SO}_{3} \rightarrow \mathrm{CaSO}_{4}+\mathrm{H}_{2} \mathrm{O} \\
& \mathrm{Ca}(\mathrm{OH})_{2}+\mathrm{HCl} \rightarrow \mathrm{CaClOH}+\mathrm{H}_{2} \mathrm{O} \\
& \mathrm{CaClOH}+\mathrm{HCl} \rightarrow \mathrm{CaCl}_{2}+\mathrm{H}_{2} \mathrm{O} \\
& \mathrm{Ca}(\mathrm{OH})_{2}+2 \mathrm{HF} \rightarrow \mathrm{CaF}_{2}+2 \mathrm{H}_{2} \mathrm{O}
\end{aligned}
$$

In parallel with the apparatus (according to the second option), an anti-filtration screen is formed in the thickness of the waste layers by jet multi-level introduction into the "body" of the landfill of $\mathrm{Mg}(\mathrm{OH})_{2}$ suspension or a mixture of adsorbents. The settled suspension effectively absorbs heavy

Fig. 2. Diagram of the device for localizing the environmental consequences of SHW ignition (the second option with an additional spray pipe): $a-$ longitudinal projection; $b$ - spray pipe: 24 - elongated frame; 25 - rotation clutch;

26 - piston; 27 - spring unit; 28 - spray nozzle; 29 - outlet inclined branch pipe;

30 - aerobic mixing nozzle; 31 - pressure sensor; 32 - suspension tank; 33 - tilt tube; 34 - mounting base; 35 - limiter; 36 - spray head; 37 - bolts

The working filler of the carriers contained in the launch units is a mixture of adsorbent substances to neutralize the average composition of the solid waste combustion products. A dry ecologically active mixture could have the following basic composition with a particle size $<1 \mathrm{~mm}$ : magnesium hydroxide $=40 \%$; montmorillonite $=20 \%$; kaolin $=20 \%$; calcium hydroxide $=20 \%$. The active ingredient of tank 32 is an aqueous suspension $\mathrm{Mg}(\mathrm{OH})_{2}$ (dry particle size is $250 \mu \mathrm{m}$ ), or a working suspension of the dry active mixture described above. This makes it possible, in the case of fire and its jet introduction into the body of the solid waste landfill, to reduce the penetration of the resulting liquid pollutants into the soil and groundwater. Magnesium hydroxide in the system could effectively be replaced by magnesium oxide ( $\mathrm{MgO})$, which also has pronounced adsorbent properties, which is due to the specific surface area, $124 \mathrm{~m}^{3} / \mathrm{g}$, and the specific volume of oxide pores, $1.038 \mathrm{~cm}^{3} / \mathrm{g}$.

To achieve maximum efficiency of the designed system under the conditions of unauthorized accumulation of waste, the device, filled with working substances and charged with carriers, is fixed with a tip in the ground in the center of the "body" of the landfill. The standby device stores electricity from rechargeable battery 13 received from the operation of panel 11, and uses it after remote radio activation of the device in the case of fire to operate the engines of the system. Activation is carried out by the dispatcher of the emergency service upon registration of a message about the ignition of waste from observers. The pressure of the air pumped into tank 3 by compressor 16 at the maximum compression of the spring-piston mechanism through pipe 10, when the power shaft of drum 2 rotates, enters compartments 19, pneumatically displacing the starting units. Further, at an altitude of 20-30 meters, the carriers of the working mixture from unit 7 are launched, and the adsorbents are subsequently sprayed in the air polluted with flue gases with adsorption and neutralization of pollutants according to the technology. The working mixture that has settled on the surface of burning waste forms a non-combustible film, contributing to the attenuation of the fire, reducing the access of oxygen to its sites. The sprayed active working mixture of adsorbents neutralizes the basic components of metals and organic toxicants from the SHW filtrate. A similar adsorption effect on heavy metals is exerted in the atmospheric air over the burning accumulation of waste, as a result of the spread of a working suspension in it. The introduction of an adsorption suspension of the full composition of the environmentally active mixture could also be carried out independently of the cases of waste ignition, without the release of carriers 7, in order to ensure the anti-filtration insulation of the landfill by forming a filtration screen. Under this mode of operation, in the installation, according to the second option, the power supply to engine 4 is remotely turned off; the upper valve in pipe 10 is closed. When supplementing the mode with a valve lock in branch pipe 29 (remotely, manually, or automatically with a predetermined frequency), the apparatus could perform regular mixing of the suspension in tank 32, preventing the solidification of the sediment fraction.

A single filling of the device with active substances is carried out on the basis of the possibility of its effective operation in at least one fire in a landfill. After the consumption of working mixtures, the unit is filled with the next portion of adsorbents.

To simplify the conditions of storage, transportation, and dosing of the filling mixture, it could be made in the form of solid dosed granules or briquettes from an alumina-aqueous solution with drying (baking) in molds. Before refueling in the apparatus, the briquettes are crushed to powder in such known crushing plants as the crushing unit, designed by us, with a pneumatic-gravity electric drive, which does not consume external electricity [34]. An adapted version of this crushing device could be an integral part of the structure of the technological system for localizing the consequences of SHW ignition.

The hardware system could be equipped with a tow hitch to connect it to the vehicle, an additional pair of transport wheels, and easily delivered to a new place of operation. The installation may also comprise a transport electric motor connected to the wheels, powered by solar panel 11, has an operator platform and a steering mechanism, which makes the technological system mobile and self-propelled. This modification eliminates the need for fuel consumption by vehicles to 
transport the refueling mixture to the place of operation of the device since it is possible to transport the system to the place of its refueling under an energy-saving mode. In this case, it is advisable to manage one landfill with two units of the system with alternating self-propelled transportation to the refueling and maintenance point, and back to the place of operation.

All the provided additional functions of modification of the considered equipment could, as a result of this study, reduce the cost of improving the environmental safety of landfills and SHW spontaneous landfills.

To substantiate the effectiveness of the designed equipment, a laboratory study of the technology was experimentally carried out to establish its practical applicability as an element of technical support for sanitary treatment schemes in urban areas.

5. 2. Results of a laboratory study into the effectiveness of using an adsorption suspension for the purification of waste filtrate

Carried out in accordance with methods specified in [27-30], our laboratory tests of the devised adsorption mixture, which is a component of the proposed technical solution, indicate that the effect of the studied sample of the mixture on the filtrate (Fig. 3) leads to a decrease in the content of controlled substances in it (Fig. 4, Table 1).

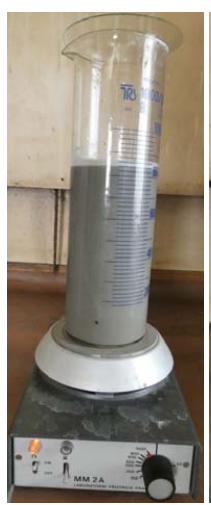

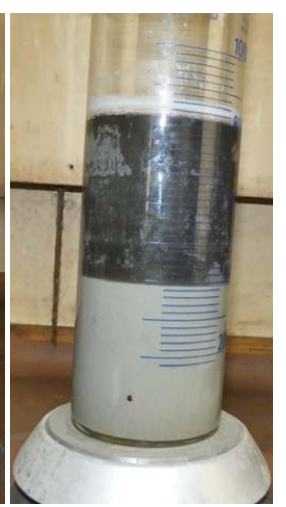

$b$

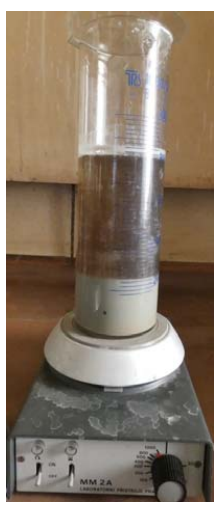

Fig. 3. Purification of waste filtrate with a working suspension of an environmentally active mixture in the laboratory: $a$ - agitating the filtrate mixture with the working suspension by a magnetic stirrer; $b$ - settling of the mixture after agitation (step No. 1 (active adsorption process)); $c$ - settling of the mixture after agitation

(step No. 2 (complete deposition of filtration precipitate))

Table 1

Results of studying the removal of components from the filtrate of the landfill

\begin{tabular}{|c|c|c|c|}
\hline Control indicator & $\begin{array}{c}\text { Measurement result } \\
\text { before suspension } \\
\text { treatment (mass } \\
\text { concentration) }\end{array}$ & $\begin{array}{c}\text { Measurement result } \\
\text { after suspension } \\
\text { treatment (mass } \\
\text { concentration) }\end{array}$ & $\begin{array}{c}\text { Remov- } \\
\text { al (\%) }\end{array}$ \\
\hline Calcium & $2,500\left(\mathrm{mg} / \mathrm{dm}^{3}\right)$ & $198\left(\mathrm{mg} / \mathrm{dm}^{3}\right)$ & 92 \\
\hline Iron, total & $136\left(\mathrm{mg} / \mathrm{dm}^{3}\right)$ & $11.7\left(\mathrm{mg} / \mathrm{dm}^{3}\right)$ & 91 \\
\hline Phosphorus, total & $44\left(\mathrm{mg} / \mathrm{dm}^{3}\right)$ & $11\left(\mathrm{mg} / \mathrm{dm}^{3}\right)$ & 75 \\
\hline Zinc & $0.48\left(\mathrm{mg} / \mathrm{dm}^{3}\right)$ & $0.33\left(\mathrm{mg} / \mathrm{dm}^{3}\right)$ & 31 \\
\hline Ammonium & $1,825\left(\mathrm{mg} / \mathrm{dm}^{3}\right)$ & $1,476\left(\mathrm{mg} / \mathrm{dm}^{3}\right)$ & 19 \\
\hline COC & $20,343\left(\mathrm{mgO} / \mathrm{dm}^{3}\right)$ & $17,300\left(\mathrm{mgO} / \mathrm{dm}^{3}\right)$ & 15 \\
\hline
\end{tabular}

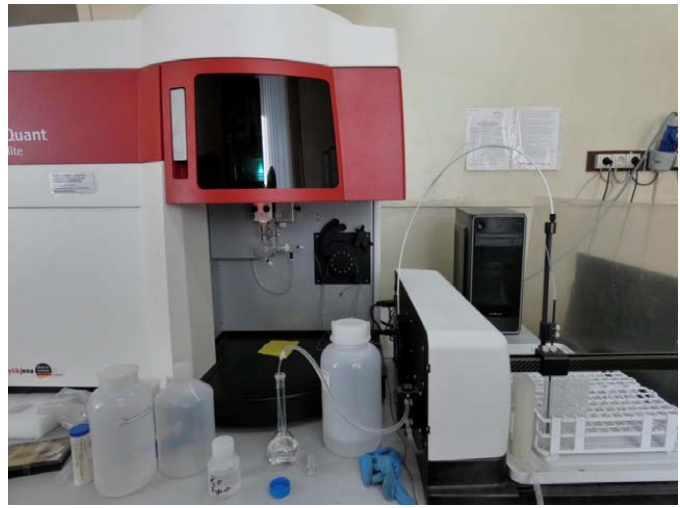

Fig. 4. Analysis of the purified waste filtrate by treating it with an aqueous adsorption suspension for the content of calcium, magnesium, phosphorus, zinc, iron, using the PlasmaQuant ${ }^{\circledR}$ PQ 9000 Elite Optical Emission Spectrometer with Inductively

Coupled Plasma (No. 13-5850E-AS230, Certificate

No. $84366 / 2$ dated 08.06.2021 (valid until 08.06.2022))

The results of studying the adsorption capacity of the ecologically active mixture are given in Table 2 .

Table 2

Results of adsorbent capacity calculation

\begin{tabular}{|c|c|c|}
\hline Control indicator & $\begin{array}{c}\text { Adsorbent capacity } \\
(\mathrm{mg} / \mathrm{kg})\end{array}$ & $\begin{array}{c}\text { Adsorbent capacity } \\
(\%)\end{array}$ \\
\hline Calcium & 11,510 & 460 \\
\hline Iron, total & 621.5 & 457 \\
\hline Phosphorus, total & 165 & 375 \\
\hline Zinc & 0.75 & 156 \\
\hline Ammonium & 1,745 & 95.6 \\
\hline COC & 15,215 & 74.8 \\
\hline
\end{tabular}

In addition, the results of laboratory tests according to the methodology given in [32] indicate an increase in the $\mathrm{pH}$ of the filtrate after its treatment.

\section{Discussion of results of devising and investigating the effectiveness of the technology for localization of environmental risks of waste ignition}

The achieved technical result of our developed solution is the reduction of environmental pollution during the ignition of SHW, due to the multifunctionality of the hardware system (Fig. 1, 2). This is expressed by the possibility of the device to neutralize the most toxic components of flue gases (4) to (10); to localize the fire by reducing the access of oxygen to the sites of ignition by settling adsorbents; to purify the filtrate before it penetrates the soil (Fig. 2). These functions of the designed equipment explain the achievement of minimization of environmental damage to the atmospheric air, soil, groundwater, water bodies, components of the landscape, which might be adjacent to specialized facilities (for example, forests, agricultural fields), and, as a result, to the human health.

The exclusion of long-range transport of pollutants by air masses and the deposition of toxic atmospheric precipitation (contaminated by ignition of wastes) is also explained by the technological possibility of adsorption of toxicants 
directly at the site of their release above the landfill. Obtaining this result is also justified by the high capacity of the proposed adsorption mixture even in the state of suspension (Table 2).

It is important to achieve the result of the economic and energy-saving efficiency of the considered technology, which is explained by the possibility of introducing its additional options such as the possible self-propelled equipment; the use of energy-autonomous crushing equipment and panels of photovoltaic converters. An environmentally and cost-effective result is the opposition of this technology to the traditional principles of waste fire elimination involving the operation of special vehicles (fire engines) and the engagement of personnel from emergency rescue services. The operation of an alternative technical solution excludes the following: financial costs for maintenance of often obsolete special vehicles and the fuels and lubricants necessary for them; involvement of numerous service personnel (payment of salaries and risks to their health). There is also no need to use environmentally unsafe synthetic mixtures for traditional firefighting, frequent difficulties in the prompt passage of special vehicles to the place of ignition of waste in populated areas.

Our laboratory studies (Fig. 3, 4) have confirmed the possibility of using an adsorption suspension when the described apparatus is employed (Fig. 2) for the purpose of cleaning the waste filtrate, its use for the formation of an anti-filtration screen in the waste mound. The property of the suspension to increase the $\mathrm{pH}$ of the SHW filtrate stimulates and explains the effective removal of metals, specifically calcium, iron, zinc (Tables 1, 2). This leads to a decrease in the overall toxicity of the solution.

The advantage of this study is the development of equipment that provides, unlike, for example, works [15, 16, 35], for the comprehensive protection of the main components of the environment - the atmosphere, hydrosphere, and lithosphere from man-made loading at sites of SHW storage. The benefit of the proposed equipment is the energy-saving, automated (or semi-automatic) background mode of operation, as well as the use of a new environmentally-friendly operating adsorption agent. The obvious merit of our laboratory tests is the use of a sample of the actual filtrate from the solid waste at Dergachev SHW landfill (Kharkiv oblast, Ukraine), which significantly enhances the reliability of experiments under controlled conditions. Qualitatively, this study highlights the use of high-precision certified laboratory equipment.

The limitations of our experiments are related to the reduced composition of the controlled parameters taken into consideration in the laboratory studies of the adsorption properties of the devised environmentally active mixture, as well as the use of only one variant of its composition.

The shortcoming of this work that must be noted is the lack of test results for the prototype of the designed hardware system; this is the next planned stage of the process of practical implementation of our study's results.

Promising areas and planned stages of further advancement of this work include the following:
- carrying out the next stage of laboratory tests of the devised technology involving an expanded composition of controlled parameters taken into consideration when conducting a study into the process of cleaning the filtrate of solid waste, as well as the air polluted during its ignition;

- testing of a prototype of the designed hardware system;

- analysis of results from the extended studies into the properties of the adsorption mixture and the operation of the prototype of the hardware system with the improvement of the composition of the adsorbent and the design of the installation for technology implementation into the schemes of sanitary treatment of urban areas.

\section{Conclusions}

1. The technology devised makes it possible to ensure a comprehensive reduction of the anthropogenic load on the main components of the environment such as the atmosphere, hydrosphere, and lithosphere at the sites of SHW storage in the event of fires. The operation of the proposed equipment, taking into consideration all the provided operating modes and additional options, is energy-saving and automated (or semi-automatic), which makes it especially relevant in modern conditions. The technology significantly increases the efficiency of the processes of eliminating the ignition of SHW and localizing its environmental consequences for the territories adjacent to polygons (or landfills), as well as for the population in the nearest settlements.

2. Our laboratory tests have proven the effectiveness of practical application, when using the designed equipment, of a new environmentally active adsorption mixture for the purpose of cleaning the waste filtrate, its use for the formation of an anti-filtration screen in SHW mounds. The tested sample of the aqueous suspension of the proposed environmentally active mixture adsorbs calcium (by $92 \%$ ), total iron (by $91 \%$ ), total phosphorus (by $75 \%$ ), zinc (by $31 \%$ ), ammonium (by $19 \%$ ), COC (by $15 \%$ ). This leads to a decrease in the overall toxicity of the solution and indicates the possibility of improving the environmental safety of waste fires when operating the proposed technical solution by cleaning the filtrate released during fires in landfills. The devised technology for the integrated localization of the environmental consequences of uncontrolled waste ignition could be used in the process of modernizing the technical support for sanitary treatment schemes in urban areas.

\section{Acknowledgments}

Part of the research reported in this article was carried out within the framework of the project "Experimental and analytical foundations for ensuring the safety of man and society by improving waste treatment technologies in the Technosphere". The work was also supported by the National Research Foundation and is the basis for the further development and implementation of the latest eco-technologies for waste management.

1. Popelo, O., Tulchynska, S., Marhasova, V., Ivanova, N., Samiilenko, H. (2021). An innovative approach to determine the sustainable development of regions by harmonization of the economic, social and environmental components. Journal of Management Information and Decision Sciences, 24 (S4), 1-9. 
2. Boichenko, S. V., Leida, K., Ivanchenko, O. V. (2016). Ekolohistyka, utylizatsiia ta retsyklinh transportnykh zasobiv: tendentsiyi ta perspektyvy rozvytku. Naukoiemni tekhnolohiyi, 2 (30), 221-227.

3. Boichenko, S. V., Lejda, K. (2015). European experience and perspectives of systems of utilization and recycling of transport means. Visnyk Natsionalnoho transportnoho universytetu, 2 (32).

4. Boichenko, S. V., Ivanchenko, O. V., Iakovlieva, A. V. (2017). Recycling and utilization of aviation engineering: the global trends and peculiarities of introduction. Science-based technologies, 2 (34), 140-149. doi: https:/doi.org/10.18372/2310-5461.34.11612

5. Boychenko, S., Shkilnuk, I., Turchak, V. (2008). The problems of biopollution with jet fuels and the way of achieving solution. Transport, 23 (3), 253-257. doi: https://doi.org/10.3846/1648-4142.2008.23.253-257

6. Shkilniuk, I., Boichenko, S. (2020). Biological Risk of Aviation Fuel Supply. Studies in Systems, Decision and Control, 179-199. doi: https://doi.org/10.1007/978-3-030-48583-2_12

7. Mar'in, V. V., Risnik, V. V., Pisarenko, V. N., Timofeev, V. B., Shishov, V. P. (2000). O probleme bytovyh othodov megapolisov i putyah ee resheniya. Gorniy informatsionno-analiticheskiy byulleten' (nauchno-tekhnicheskiy zhurnal), 10.

8. Kutniashenko, O., Smoliaga, V., Litvinova, T. (2016). Improving the efficiency of household waste recycling by pre-preparation of their dispersed fraction. Polytechnic magazine Metal. Journal - Metallurgical and Mining Industry, 8, 6-14.

9. Kurilenko, V. V., Osmolovskaya, N. G., Maksimova, D. A., Kuchaeva, L. N. (2015). Geo-ecological characteristics of kronstadt and assessment of its territory pollution by heavy metals. Vestnik SPbGU, 2, 107-124.

10. Podlipskiy, I. I. (2013). Geoekologicheskaya otsenka prilegayuschih territoriy poligona bytovyh othodov (g. Pitkyaranta, Respublika Kareliya). Vestnik Sankt-Peterburgskogo universiteta. Nauki o Zemle, 2, 48-56.

11. Chrysikou, L., Gemenetzis, P., Kouras, A., Manoli, E., Terzi, E., Samara, C. (2008). Distribution of persistent organic pollutants, polycyclic aromatic hydrocarbons and trace elements in soil and vegetation following a large scale landfill fire in northern Greece. Environment International, 34 (2), 210-225. doi: https://doi.org/10.1016/j.envint.2007.08.007

12. Kazantseva, L. A., Sippel, A. E. (2018). Environmental and fire danger of a solid waste landfill within the territory of the Sorokinsky raion (the Tyumen oblast). Vestnik Moskovskogo universiteta. Seriya 5. Geografiya, 5, 22-26. Available at: https://cyberleninka.ru/ article/n/ekologicheskaya-i-pozharnaya-opasnost-poligona-tverdyh-bytovyh-othodov-na-territorii-sorokinskogo-rayonatyumenskoy-oblasti

13. Cocean, I., Diaconu, M., Cocean, A., Postolachi, C., Gurlui, S. (2020). Landfill Waste Fire Effects Over Town Areas Under Rainwaters IOP Conference Series: Materials Science and Engineering, 877, 012048. doi: https://doi.org/10.1088/1757-899x/877/1/012048

14. Pan, Y., Yang, L., Zhou, J., Liu, J., Qian, G., Ohtsuka, N. et. al. (2013). Characteristics of dioxins content in fly ash from municipal solid waste incinerators in China. Chemosphere, 92 (7), 765-771. doi: https://doi.org/10.1016/j.chemosphere.2013.04.003

15. Dos Muchangos, L. S., Tokai, A. (2020). Greenhouse gas emission analysis of upgrading from an open dump to a semi-aerobic landfill in Mozambique - the case of Hulene dumpsite. Scientific African, 10, e00638. doi: https://doi.org/10.1016/j.sciaf.2020.e00638

16. Wang, K., Nakakubo, T. (2020). Comparative assessment of waste disposal systems and technologies with regard to greenhouse gas emissions: A case study of municipal solid waste treatment options in China. Journal of Cleaner Production, 260, 120827. doi: https://doi.org/10.1016/j.jclepro.2020.120827

17. Weichenthal, S., Van Rijswijk, D., Kulka, R., You, H., Van Ryswyk, K., Willey, J. et. al. (2015). The impact of a landfill fire on ambient air quality in the north: A case study in Iqaluit, Canada. Environmental Research, 142, 46-50. doi: https://doi.org/10.1016/ j.envres.2015.06.018

18. Van den Berg, M., Birnbaum, L. S., Denison, M., De Vito, M., Farland, W., Feeley, M. et. al. (2006). The 2005 World Health Organization Reevaluation of Human and Mammalian Toxic Equivalency Factors for Dioxins and Dioxin-Like Compounds. Toxicological Sciences, 93 (2), 223-241. doi: https://doi.org/10.1093/toxsci/kfl055

19. Faqi, A. S., Dalsenter, P. R., Merker, H.-J., Chahoud, I. (1998). Reproductive Toxicity and Tissue Concentrations of Low Doses of 2,3,7,8-Tetrachlorodibenzo-p-Dioxin in Male Offspring Rats Exposed Throughout Pregnancy and Lactation. Toxicology and Applied Pharmacology, 150 (2), 383-392. doi: https://doi.org/10.1006/taap.1998.8433

20. Wiwanitkit, V. (2016). Thai waste landfill site fire crisis, particular matter 10, and risk of lung cancer. Journal of Cancer Research and Therapeutics, 12 (2), 1088. doi: https://doi.org/10.4103/0973-1482.172120

21. Vassiliadou, I., Papadopoulos, A., Costopoulou, D., Vasiliadou, S., Christoforou, S., Leondiadis, L. (2009). Dioxin contamination after an accidental fire in the municipal landfill of Tagarades, Thessaloniki, Greece. Chemosphere, 74 (7), 879-884. doi: https:// doi.org/10.1016/j.chemosphere.2008.11.016

22. Cunliffe, A. M., Williams, P. T. (2009). De-novo formation of dioxins and furans and the memory effect in waste incineration flue gases. Waste Management, 29 (2), 739-748. doi: https://doi.org/10.1016/j.wasman.2008.04.004

23. Wang, G., Fan, Z., Wu, D., Qin, L., Zhang, G., Gao, C., Meng, Q. (2014). Anoxic/aerobic granular active carbon assisted MBR integrated with nanofiltration and reverse osmosis for advanced treatment of municipal landfill leachate. Desalination, 349, 136-144. doi: https://doi.org/10.1016/j.desal.2014.06.030

24. Cabral, M., Garçon, G., Touré, A., Bah, F., Dewaele, D., Bouhsina, S. et. al. (2021). Renal impairment assessment on adults living nearby a landfill: Early kidney dysfunction biomarkers linked to the environmental exposure to heavy metals. Toxicology Reports, 8, 386-394. doi: https://doi.org/10.1016/j.toxrep.2021.02.009

25. Peng,Y.(2017). Perspectives on technology forlandfillleachatetreatment.Arabian JournalofChemistry, 10,S2567-S2574.doi:https:// doi.org/10.1016/j.arabjc.2013.09.031 
26. Anna Tałałaj, I., Bartkowska, I., Biedka, P. (2021). Treatment of young and stabilized landfill leachate by integrated sequencing batch reactor (SBR) and reverse osmosis (RO) process. Environmental Nanotechnology, Monitoring \& Management, 16, 100502. doi: https://doi.org/10.1016/j.enmm.2021.100502

27. Kumar, G., Reddy, K. R., McDougall, J. (2020). Numerical modeling of coupled biochemical and thermal behavior of municipal solid waste in landfills. Computers and Geotechnics, 128, 103836. doi: https://doi.org/10.1016/j.compgeo.2020.103836

28. Fiorineschi, L., Frillici, F. S., Rotini, F. (2018). Enhancing functional decomposition and morphology with TRIZ: Literature review. Computers in Industry, 94, 1-15. doi: https://doi.org/10.1016/j.compind.2017.09.004

29. MVV No. 081/12-0317-06. Poverkhnevi, pidzemni ta zvorotni vody. Metodyka vykonannia vymiriuvan vodnevoho pokaznyka (rN) elektrometrychnym metodom. Available at: https://budstandart.ua/normativ-document.html?id_doc=76469

30. MVV No. 081/12-0106-03. Poverkhnevi, pidzemni ta zvorotni vody. Metodyka vykonannia vymiriuvan masovoi kontsentratsiyi amoniy-ioniv fotokolorymetrychnym metodom z reaktyvom Neslera. Zi zminoiu No. 1. Available at: http://online.budstandart.com/ ua/catalog/doc-page?id_doc $=76427$

31. MVV No. 081/12-0647-09. Metodyka vykonannia vymiriuvan masovoi kontsentratsiyi KhSK u zvorotnykh, poverkhnevykh i pidzemnykh vodakh fotokolorymetrychnym metodom u diapazoni vid $4 \mathrm{mhO} / \mathrm{dm}^{3} \mathrm{do} 10000 \mathrm{mhO} / \mathrm{dm}^{3}$ vkliuchno (z vykorystanniam testovoi sumishi reahentiv na vyznachenyi diapazon vymiriuvannia KhSK) (tilky dlia fotometriv abo spektrofotometriv typu PhotoLab Spectral, Spectroquant NOVA, Spektroflex, DR abo analohichnykh). Available at: http://online.budstandart.com/ua/ catalog/doc-page?id_doc $=76576$

32. Bondarenko, I. V., Kutniashenko, O. I. (2019). Pat. No. 139374 UA. Systema dlia skorochennia ekolohichnoho zabrudnennia navkolyshnoho seredovyshcha pry pozhezhakh na polihonakh TPV ta v umovakh stykhiynykh smittiezvalyshch. No. a201902114; declareted: 01.03.2019; published: 10.01.2019, Bul. No. 1.

33. Bondarenko, I. V. (2012). Pat. No. 103811 UA. Snariad dlia ekolohichnoho ochyshchennia atmosfernoho povitria. No. a201201731; declareted: 16.02.2012; published: 25.11.2013. Bul. No. 22.

34. Bondarenko, I. V. (2013). Pat. No. 111828 UA. Drobylnyi ahrehat z hravitatsiino-pnevmatychnym elektropryvodom. No. a201304265; declareted: 05.04.2013; published: 24.06.2016, Bul. No. 12.

35. Kieush, L., Schenk, J., Pfeiffer, A., Koveria, A., Rantitsch, G., Hopfinger, H. (2022). Investigation on the influence of wood pellets on the reactivity of coke with CO2 and its microstructure properties. Fuel, 309, 122151. doi: https://doi.org/10.1016/ j.fuel.2021.122151 